\title{
Studies on the Enzyme in Young Mycelia of Aspergillus Oryzae.
}

\author{
By Yoshio Otani. \\ From the Zymomycological Institute, Imperial College of Agriculture, Tottori, Japan.
}

(Received Mar, 7, 1939.)

INTRODUCTION.

There are many kinds of enzymes produced by Aspergillus Oryzae. There is no need of giving special references to literature on this subject as the fact is well known. ${ }^{(1 \sim \infty)}$ All of the literature makes references to enzymes in the full growth of the mycelia mass of this fungus. In this study, the author made experiments especially with young mycelia, the word "young mycelia" being used in the sense of fungus which has been cultivated but on which no spores have yet grown. Recently, especially in Japan, in the industrial use, i. e., in brewing Japanese saké and in manufacture of medicines, young mycelia of this fungus are very largely used. So the author undertook to study the enzymes in the young mycelia of this mold, and he will now describe 13 kinds of enzymes which he found in this experiment.

\section{EXPERIMENT.}

Materials and Enzyme Solution.

The materials used in this experiment were prepared in the following manner; the fungus was inoculated in a synthetic solution, and waiting until there was a sufficient growth of mycelia, they were taken off and washed with water, dried at a low temperature, and ground into powder. The enzymatic solution was prepared as follows :- one gram of the above mentioned fungus powder put into $100 \mathrm{cc}$ of distilled water and left for four hours at a temperature of $40^{\circ} \mathrm{C}$, the mixture being frequently stirred. The solution was then put through a Zeitz-filter, and the clear solution thus produced was used.

\section{Results of the Experiment.}

1. $\beta$-h-Fructosidase: This enzyme acted on one mol of saccharose and hydrolysed it into one mol of glucose and one mol of fructose. The following method was used to measure the enzyme action: $2 \%$ saccharose was used as substrate, $10 \mathrm{cc}$ of it was put into a test-tube, and $5 \mathrm{cc}$ of the enzyme solution was added. In order to keep the solution from putrifying $0.5 \mathrm{cc}$ toluen was added. The mixtare was left in a thermostat at $40^{\circ} \mathrm{C}$, for 24 hours. After which it was 
put in into a boiling water bath to stop the action of the enzyme. All the fluid was then put into a graduated flask, water was added and the whole solution ${ }^{\circ}$ was increased to a volume of $50 \mathrm{cc}, 20 \mathrm{cc}$ of this was taken and the amount of reducing sugar was measured according to the BerTrand method. From this value that of blank test was deducted and with the remaining number, the power of this enzyme was showen by remaining value.

Table 1.

a : $2 \%$ saccharose solution $10 \mathrm{cc}+1 \%$ enzyme solution $5 \mathrm{cc}+$ toluen $0.5 \mathrm{cc}$.

b : $2 \%$ saccharose solution $10 \mathrm{cc}+1 \%$ boiled enzyme $5 \mathrm{cc}+$ toluen $0.5 \mathrm{cc}$.

Incubation at $40^{\circ} \mathrm{C}$ for 24 hours.

\begin{tabular}{c|c|c|c}
\hline \multirow{2}{*}{ Experiment number } & \multicolumn{3}{|c}{$0.5 \% \mathrm{KMnO}_{4}$ solution (cc) } \\
\cline { 2 - 4 } & $\mathrm{a}$ & $\mathrm{b}$ & $\mathrm{a}-\mathrm{b}$ \\
\hline 1 & 4.00 & 0.35 & 3.65 \\
2 & 4.00 & 0.40 & 3.60 \\
\hline
\end{tabular}

As shown in table 1 , there is a strong $\beta$ - $h$-fructosidase in the young mycelia of Aspergillus Oryzae.

2. $\alpha$-d-Glucosidase: This is an enzyme which hydrolyse $\boldsymbol{a}$-maltose or $\boldsymbol{a}$ glucoside. In general, there is maltase in this enzyme. A $2 \%$ maltose solution

Table 2.

a : $2 \%$ maltose solution $10 \mathrm{cc}+1 \%$ enzyme solution $5 \mathrm{cc}+$ toluen $0.5 \mathrm{cc}$.

b : $2 \%$ maltose solution $10 \mathrm{cc}+1 \%$ boiled enzyme $5 \mathrm{cc}+$ toluen $0.5 \mathrm{cc}$.

Incubation at $40^{\circ} \mathrm{C}$ for 24 hours.

\begin{tabular}{c|c|c|c}
\hline \multirow{2}{*}{ Experiment number } & \multicolumn{3}{|c}{$0.5 \% \mathrm{KMnO}_{4}$ solution (cc) } \\
\cline { 2 - 4 } & $\mathrm{a}$ & $\mathrm{b}$ & $\mathrm{a}-\mathrm{b}$ \\
\hline 1 & 10.95 & 9.30 & 1.65 \\
2 & 10.95 & 9.20 & 1.75 \\
\hline
\end{tabular}

was used as a substrate to measure this enzyme. When the enzymatic action was finished, the results were obtained by the BERTrANi method.

As seen from the above table, $a$-d-glucosidase "can be clearly demonstrated in this enzyme solution. 
3. $\beta$-d-Galactosidase: This enzyme is also called lactase. It decomposes lactose into galactose and glucose. We used as a substrate a $2 \%$ lactose solution. As mentioned above, the enzymatic decomposition product was measured by the BERTRANI) method with the following results:

Table 3.

a : $2 \%$ lactose solution $10 c c+1 \%$ enzyme solution $5 \mathrm{cc}+$ toluen $0.5 \mathrm{cc}$.

b : $2 \%$ lactose solution $10 \mathrm{cc}+1 \%$ boiled enzyme $5 \mathrm{cc}+$ toluen $0.5 \mathrm{cc}$.

Incubation at $40^{\circ} \mathrm{C}$ for 24 hours.

\begin{tabular}{c|c|c|c}
\hline \multirow{2}{*}{ Fxperiment number } & \multicolumn{3}{|c|}{$0.5 \% \mathrm{KMnO}_{4}$ solution (cc) } \\
\hline 1 & $\mathrm{a}$ & $\mathrm{b}$ & $\mathrm{a}-\mathrm{b}$ \\
\hline 2 & 10.30 & 9.00 & 1.30 \\
& 10.30 & 9.00 & 1.30 \\
\hline
\end{tabular}

As indicated in table 3 , this enzyme solution contained very little $\beta$ - $d$ glucosidase.

4. $\beta$-d-Glucosidase: There is emulsin, in general, in this enzyme. In this experiment, amygdalin was used as substrate.

Table 4.

a : $2 \%$ amygdalin solution $10 c c+1 \%$ enzyme solution $5 \mathrm{cc}+$ toluen $0.5 \mathrm{cc}$.

b : $2 \%$ amygdalin solution $10 \mathrm{cc}+1 \%$ boild enzyme $5 \mathrm{cc}+$ toluen $0.5 \mathrm{cc}$.

Incubation at $40^{\circ} \mathrm{C}$ for 24 hours.

\begin{tabular}{c|c|c|c|}
\hline \multirow{2}{*}{ Experiment number } & \multicolumn{3}{|c|}{$0.5 \% \mathrm{KMnO}_{4}$ solution (cc) } \\
\cline { 2 - 4 } & $\mathrm{a}$ & $\mathrm{b}$ & $\mathrm{a}-\mathrm{b}$ \\
\hline 1 & 18.2 & 0 & 18.2 \\
2 & 18.2 & 0 & 18.2 \\
\hline
\end{tabular}

As noted in the above table, emulsin in this fungus enzyme worked very powerfully.

5. a-Amylase: In order to find out whether this enzyme was present or not, a starch solution was used, and the experiment was carried out through iodine reaction. $5 \mathrm{cc}$ of this enzyme solution was added to $10 \mathrm{cc}$ of $2 \%$ soluble starch solution, and was left at a temperature of $40^{\circ} \mathrm{C}$ for one hour. Then, iodine was added to the solution which gave it a red-brown colour, when a boiled solution of 
this enzyme was used, and iodine added, it showed a blue colour. Thus we concluded that this fungus enzyme contained strong $a$-amylase enzyme.

6. $\beta$-Amylase: This enzyme is one which saccharifies starch. So we used $2 \%$ soluble starch as substrate and allowed this enzyme to act on it. The amount of sugar produced was measured by the BERTRANI method.

Table 5.

a : $2 \%$ soluble starch solution $10 \mathrm{cc}+1 \%$ enzyme solution $5 \mathrm{cc}+$ toluen $0.5 \mathrm{cc}$.

b : $2 \%$ soluble starch solution $10 \mathrm{cc}+1 \%$ boiled enzyme $5 \mathrm{cc}+$ toluen $0.5 \mathrm{cc}$.

Incubation at $40^{\circ} \mathrm{C}$ for 24 hours.

\begin{tabular}{c|c|c|c}
\hline \multirow{3}{*}{ Experiment number } & \multicolumn{3}{|c}{$0.5 \% \mathrm{KMnO}_{4}$ solution (cc) } \\
\cline { 2 - 4 } & $\mathrm{a}$ & $\mathrm{b}$ & $\mathrm{a}-\mathrm{b}$ \\
\hline 1 & 9.70 & 5.00 & 4.70 \\
2 & 9.60 & 5.00 & 4.60 \\
\hline
\end{tabular}

Table 5 shows that this enzyme solution showed strong $\beta$-amylase.

7. Papain type protease: This enzyme is one of the proteinase which has about pH 5.2 optimum hydrogen ion concentration. In our experiment, we used gelatin and casein as substrates on which we allowed this enzyme to work. Then we measured the amino acid produced by the SöRENSEN method, with the following result :-

Table 6.

a : $2 \%$ gelatin solution (or $4 \%$ casein solution) $10 \mathrm{cc}+1 \%$ enzyme solution $5 \mathrm{cc}+$ toluen $0.5 \mathrm{cc} \ldots . . . \mathrm{pH} 5.2$.

b : $2 \%$ gelatin solution (or $4 \%$ casein solution) $10 \mathrm{cc}+1 \%$ boiled enzyme $5 \mathrm{cc}+$ toluen $0.5 \mathrm{cc} \ldots . . . \mathrm{pH} 5.2$.

Incubation at $40^{\circ} \mathrm{C}$ for hours.

\begin{tabular}{c|c|c|c|c}
\hline \multirow{3}{*}{ Substrata } & \multirow{2}{*}{$\begin{array}{c}\text { Experiment } \\
\text { number }\end{array}$} & \multicolumn{3}{|c}{$N / 10 \mathrm{Ba}(\mathrm{OH})_{2}$ solution (cc) } \\
\cline { 3 - 5 } & & $\mathrm{a}$ & $\mathrm{b}$ & $\mathrm{a}-\mathrm{b}$ \\
\hline Gelatin & 1 & 0.70 & 0.45 & 0.25 \\
$\prime \prime$ & 2 & 0.70 & 0.50 & 0.20 \\
Casein & 1 & 1.20 & 0.60 & 0.60 \\
$\prime \prime$ & 2 & 1.25 & 0.60 & 0.65 \\
\hline
\end{tabular}

In the above table, it can be clearly seen that in this enzyme solution, there is papain type proteinase.

8. Peptide decomposing enzyme: This peptide decomposing enzyme is one which decomposes peptone at about $\mathrm{pH}$ 8.0. Using peptone as a substrate of this enzyme, we measured the amino acid produced after the reaction, through the SöRENSEN method, 
Table 7.

a : $2 \%$ peptone solution $10 \mathrm{cc}+1 \%$ enzyme solution $5 \mathrm{cc}+$ toluen $0.5 \mathrm{cc}$.

b : $2 \%$ peptone solution $10 \mathrm{cc}+1 \%$ boiled enzyme $5 \mathrm{cc}+$ toluen $0.5 \mathrm{cc}$.

Incubation at $40^{\circ} \mathrm{C}$ for 24 hours.

\begin{tabular}{c|c|c|c}
\hline \multirow{2}{*}{ Experiment number } & \multicolumn{3}{|c|}{$N / 10 \mathrm{Ba}(\mathrm{OH})_{2}$ solution (cc) } \\
\cline { 2 - 4 } & $\mathrm{a}$ & $\mathrm{b}$ & $\mathrm{a}-\mathrm{b}$ \\
\hline 1 & 3.80 & 1.95 & 1.90 \\
2 & 3.85 & 1.95 & 1.95 \\
\hline
\end{tabular}

As shown in the above table, it can be easily seen that in this enzyme solution, there is peptide decomposing enzyme.

9. Lab: In order to test the lab enzyme, the following two methods were used.

1st experiment :- Using fat free milk, pasteurized.

Table 8.

a : Fat free milk $10 \mathrm{cc}+1 \%$ enzyme solution $5 \mathrm{cc}+$ toluen $0.5 \mathrm{cc}$.

b : Fat free milk $10 \mathrm{cc}+1 \%$ boiled enzyme $5 \mathrm{cc}+$ toluen $0.5 \mathrm{cc}$.

Incubation at $40^{\circ} \mathrm{C}$ for 24 hours.

\begin{tabular}{c|c|c}
\hline Experiment number & $a$ & $b$ \\
\hline 1 & $\begin{array}{l}\text { coagulated } \\
\text { coagulated }\end{array}$ & $\begin{array}{l}\text { not coagulated } \\
\text { not coagulated }\end{array}$ \\
\hline
\end{tabular}

2nd experiment :- Using casein solution.

$1.5 \mathrm{~g}$ casein was dissolved in $25 \mathrm{cc}$ of sodium bi-phosphate solution, and was mixed with $25 \mathrm{cc}$ of $0.4 \%$ calcium chloride solution, the mixture being used as substrate.

Table 9.

a : Casein solution $10 \mathrm{cc}+1 \%$ enzyme solution $5 \mathrm{cc}+$ toluen $0.5 \mathrm{cc}$.

b : Casein solution $10 \mathrm{cc}+1 \%$ boiled enzyme $5 \mathrm{cc}+$ toluen $0.5 \mathrm{cc}$.

Incubation at $40^{\circ} \mathrm{C}$ for 24 hours.

\begin{tabular}{c|c|c}
\hline Experiment number & $a$ & $b$ \\
\hline 1 & $\begin{array}{l}\text { coagulated } \\
\text { coagulated }\end{array}$ & $\begin{array}{l}\text { not coagulated } \\
\text { not coagulated }\end{array}$ \\
\hline
\end{tabular}

As shown by the experiment, in this enzyme solution, there was lab coagulating milk and casein.

10. Urease: In $10 \mathrm{cc}$ of $2 \%$ urea solution was added $5 \mathrm{cc}$ of this enzyme solution and $0.5 \mathrm{cc}$ of toluen. This was kept, for a whole day, in a bath at a constant temperature of $40^{\circ} \mathrm{C}$. When NessLer reagent was added, it produced a 
clear reddish brown colour. By this, we could see that there was urease in this enzyme solution. In addition we used as blank test, a boiled solution of this enzyme, but the reaction was negative.

11. Peroxidase : $5 \mathrm{cc}$ of $1 \%$ pyrogallic acid was mixed with $5 \mathrm{cc}$ of $3 \%$ hydrogen peroxide and to this was added $5 \mathrm{cc}$ of this enzyme solution. When this was left in a room at a temperature of ca. $20^{\circ} \mathrm{C}$, purpurgallin crystals were clearly seen. But when boiled enzyme were used as control test, the reaction was negative.

12. Indophenolase: To this fungus enzyme, a few drops of "Nadi" reagent were added. After 30 minutes, or an hour, a rose-red or red-violet colour appeared, but the blank test was negative.

13. Catalase: $1 \%$ hydrogen peroxide was used as substrate and was added to the enzyme solution. Using permanganate solution, the reaction was tested.

Table 10.

a : $1 \%$ hydrogen peroxide solution $+10 \mathrm{cc}$ enzyme solution $5 \mathrm{cc}$.

b : $1 \%$ hydrogen peroxide solution $+10 \mathrm{cc}$ boiled enzyme $5 \mathrm{cc}$.

Incubation at $40^{\circ} \mathrm{C}$ for 30 minutes.

\begin{tabular}{c|c|c|c}
\hline \multirow{2}{*}{ Experiment number } & \multicolumn{3}{|c}{$0.5 \% \mathrm{KMnO}_{4}$ solution (cc) } \\
\cline { 2 - 4 } & $\mathrm{a}$ & $\mathrm{b}$ & $\mathrm{a}-\mathrm{b}$ \\
\hline 1 & 1.90 & 0.30 & 1.60 \\
2 & 1.90 & 0.30 & 1.60 \\
\hline
\end{tabular}

As shown in the above table, this enzyme certainly has catalase action.

\section{Summary.}

This study was made in order to test the enzymes which are produced by young mycelia of Aspergillus Oryzae. It was found that there were 13 kinds of enzymes, i. e., $\beta$ - $h$-fructosidase (saccharase), $\alpha$ - $d$-glucosidase (maltase), $\beta$ - $d$-galactosidase (lactase), $\beta$ - $d$-glucosidase (emulsin), $\alpha$-amylase, $\beta$-amylase, papain type protease, peptide decomposing enzyme, lab, urease, peroxidase, indophenolase and catalase.

Among these, peroxidese and indophenolase were weak.

A report will probably be made later of enzymes other than those noted above.

\section{Bibliography.}

(1) Thom, C., and Church, M.: The Aspergilli, 59, (1926).

(2) Buchanan,|R. E., and Fulmer, E. I.: Physiology and Biochemistry of Bacteria, III, 33 -157 (1930). 